\title{
The Midnight Ride of Kwame Nkrumah and Other Fables of Bandung (Ban-doong)
}

Robert Vitalis

The battle against colonialism has been a long one, and do you know that today is a famous anniversary in that battle? On the eighteenth day of April, on thousand seven hundred and seventy five, just one hundred and eighty years ago, Paul Revere rode at midnight through the New England countryside, warning of the approach of British troops and of the opening of the American War of Independence, the first successful anti-colonial war in history. About this midnight ride the poet Longfellow wrote:

A cry of defiance, and not of fear, $A$ voice in the darkness, a knock at the door, And a word that shall echo for evermore! ${ }^{1}$

Two conferences were held at Bandung in April 1955. One was the real conference, about which not very much is known, about which people care even less, and which has faded away like a bad dream. The other was a quite different conference, a crystallization of what people wanted to believe had happened which, as a myth, took on reality in the Bandung Principles and, later, in the Bandung Spirit. The real conference aroused interest mainly because it contributed towards the solution of a crisis then much in the news but which history scarcely troubles to record. ${ }^{2}$

Myths or the identity stories a group tells about itself are found not just in grade school primers or nationalist tracts but also in advanced scholarship, in professional journals, and in conference papers. In 2005, the fiftieth anniversary of the Asian-African Conference at Bandung, Indonesia I attended a combined session of the Middle East and African Studies Associations titled "Bandung at 50: Histories of Resistance and Legacies of Solidarities." Adnan A. Husain and Rabab Abdulhadi organized the session, reprising one they put together earlier at the World Social Forum in Porto Alegre, Brazil. One of the panel members, Poonam Arora, a specialist in

Author's Note: I wrote the first draft of this paper for the February 2009 Columbia University Workshop, "Contending with the Superpowers: The Non-Aligned Movement in the Mediterranean," the first research and writing I did following my father's death the previous summer. I am grateful to Victoria de Grazia for giving me a reason to head back to the archives, and to the amazing historian of Yugoslavian foreign policy, Rinna Kullaa, who worked overtime getting me up to speed. Itty Abraham, Jeff Byrne, Ron Granieri, Guy Laron, Roger Owen, Jason Parker, Adolph Reed, and Brad Simpson have offered help as I wrestled with the challenges of two sharp, reliable critics and friends, Hisham Aidi and Zachary Lockman. I may still have not gotten it right.

${ }^{1}$ President Sukarno at the Opening of the Asian-African Conference, April 18, 1955, Appendix to George Kahin, The Asian-African Conference: Bandung, Indonesia, April 1955 (Ithaca: Cornell University Press, 1956), p. 44.

${ }^{2}$ G. H. Jansen, Afro-Asia and Non-Alignment (London: Faber and Faber, 1966), p. 182.

The Cold War in the Mediterranean Project The European Institute, Columbia University
DRAFT Working Paper Do not cite or quote without author's permission 
third world film studies of the University of Michigan-Dearborn, titled her talk "Bandung at 50 : Judgment on the World or Shift in Consciousness?" Striking a personal note, Professor Arora spoke about how, as a young Indian woman, she had learned of and been inspired by the presence of Gold Coast prime minister Kwame Nkrumah at Bandung. There was just one small problem, I said, during the discussion, having read Scotland Yard's confidential records on Nkrumah at the British National Archives in Kew the year before. Nkrumah was never there.

It turns out that Bandung is the imagined birthplace of not one but two global "solidarities" that some professors continue to confuse with (for lack of a better term) the historical process, and that in many cases they elide into one. The first is routinely referred to as "non-alignment" or the non-aligned movement. The second is a bit more unwieldy, an emerging "global racial consciousness" or a movement of the "darker nations." This article challenges both these ways of thinking about the politics of Bandung and its aftermath. The problem is that these myths are no more firmly rooted in reality than the imagined presence of Nkrumah.

They continue to exist not least because so little scholarship has sought to explore them. No historians have published studies based on research in the archives of the actually existing international organization, the Non-Aligned Movement (or NAM), founded in Belgrade in 1961 at the First Conference of Heads of State or Government of Non-Aligned Countries, not at Bandung in 1955. It is headquartered in New York with a rotating chairmanship currently held by the president of Egypt, Husni Mubarak. ${ }^{4}$ The major scholarship on NAM is now a few decades old, produced mostly by journalists and political scientists specializing in international relations, and still worth reading—not least for the routine warnings to avoid what political scientist Peter Willetts called the "distortions of history" that solidarities produce.

\footnotetext{
${ }^{3}$ Vijay Prashad, The Darker Nations: A People's History of the Third World (New York: New Press, 2007).

${ }^{4}$ I base this claim on my participation in the Columbia University-organized Conference Group on the Non-Aligned Mediterranean and in exchanges with the Princeton workshop group-information whose co-convenors are Christopher Parker and Bradley Simpson. See as well Rinna Kullaa, Non-Alignment and its Origins in Cold War Europe: Yugoslavia, Finland and the Soviet Challenge (London: IB Taurus, 2011) forthcoming.
} 
He was referring to speeches by the Nigerian and Sri Lankan ambassadors at a 1976 Howard University conference marking the twenty-fifth anniversary of NAM. Both diplomats recalled that the road to Belgrade had passed through Bandung. The Cuban and Yugoslavian ambassadors, from key states in NAM's founding that were neither Asian nor African, disagreed, on grounds beyond those of identity or their own leaderships' legitimization strategies. As Willetts put it, and this is a key point, "Bandung in its composition and its decisions was the antithesis of non-alignment. ${ }^{5}$ Willetts was updating an already existing, well documented and argued interpretation, one which political scientist Itty Abraham sustains in his 2009 account of Indian foreign policy change. ${ }^{6}$ Through the mid 1960s the rival Asian-African and Non-Aligned frameworks reflected ongoing divisions and competing hegemonic ambitions of, to take just one example I explore in this article, Nasser in Egypt and Kwame Nkrumah in Ghana. The Bandungto-Belgrade story that many tell now is best understood as part of that multi-front war of position as states and their organic intellectuals began to recast events to fit the line of the day.

Willetts could have said much more about "distortions" at a conference where Howard University political scientist James Garrett called on African-Americans to join the other nonaligned "nations" at the upcoming sixth summit in Havana in 1979. ${ }^{7}$ According to Garrett, Malcolm X had clarified, even if in somewhat narrow terms, why it was important to do so in the landmark

${ }^{5}$ Peter Willetts, review of The Third World Without Superpowers: The Collected Documents of the Non-Aligned Movement, Odette Jankowitsch and Karl Sauvant, eds., 4 volumes (1979), and The Non-Aligned Movement in World Politics, A. W. Singham, ed. (1978), in International Affairs 55, 3 (1979), pp. 439-441. He develops the point at much greater length and to devastating effect, at least if one believes in the value of rationally persuasive argument over folk tales, in his own The Non-Aligned Movement: The Origins of a Third World Alliance (London: Pinter, 1978).

${ }^{6}$ Itty Abraham, From Bandung to NAM: Non-Alignment and Indian Foreign Policy, 1947-65, Commonwealth and Comparative Studies, 46, 2 (2009), pp. 195-219.

${ }^{7}$ See James Garrett, "Afro-Americans and American Foreign Policy," in Singham, ed. NonAligned Movement, pp. 217-221. Garrett appears not to understand how the summits were organized else is confusing them with solidarity organization meetings where indeed one might send a delegation. The meetings of Heads of States had categories of observers and guests but these also were states, regional organizations of states such as the Arab League, the Islamic League, the OUA, and would be states in the form of liberation organizations, the PLO, SWAPO, and so forth. 
1963 speech at the Northern Negro Grassroots Leadership Conference. ${ }^{8}$ Malcolm X reads it in terms of the binary through which Americans saw the world and that continues to shape the histories being produced today. It was the "first unity meeting in centuries of black people" who had transcended their differences primarily through their recognition of the white man as the number one enemy. ${ }^{9}$ Going to Havana might not have seemed so strange a proposal to a Howard audience in 1976 either had two stalwart internationalists, W.E.B. Du Bois and Paul Robeson, found a way around the state department travel ban twenty years before, since, Garrett believed that both had been "invited to participate in the Bandung Conference." ${ }^{10}$ My colleague at the University of Pennsylvania, Adolph Reed, Jr, who was then teaching political science at Howard, responded by condemning the turn to "Black Third Worldism." It is an essay that ought to be on the reading lists now. ${ }^{11}$

The historical scholarship that began to appear on these same matters ten years after Howard's anniversary volume on the Belgrade summit and thirty years after the Asian-African conference has sought to write African American internationalism "into" and thus revise Cold War

${ }^{8}$ The politics surrounding the competing leadership conferences that same weekend in Detroit is well known to historians of the civil rights movements and its radical critics. For one recent account see Peniel E. Joseph, Waiting 'Til the Midnight Hour: A Narrative History of Black Power in America (New York: Macmillan, 2007), pp. 87-92. We might consider the lessons for writing better histories of the diverse tendencies and conflicts underpinning the states meeting at Bandung and elsewhere in the 1950s and 1960s (and beyond).

${ }^{9}$ The federally funded partnership with Ashland University's Ashbrook Center, TeachingAmericanHistory.org, gets the title "Message to [the] Grassroots," and date, November 10,1963 , not October 10,1963, wrong on its website for teachers! At least the text is reliable. http://teachingamericanhistory.org/library/index.asp?document=1145, accessed Feb. 4, 2010.

${ }^{10}$ Columbo powers issued invitations only to states and their representatives. Nonetheless the strange and false claim about Du Bois's invitation is kept alive in Gerald Horne and Mary Young, eds., W.E.B. Du Bois: An Encyclopedia, entry titled "Bandung Conference," by Kenneth Mostern (Greenwood Publishing, 2001), pp. 23-24.

${ }^{11}$ Demonstrating a clearer understanding than the Third Worldists of what NAM was about in the 1970s and how the answers Third Worldism supplied grew more esoteric "as actual opposition motion... atrophied," Reed presses them: "What foreign trade and investment arrangements are critical matters within the US Black community? What are our products which cause AfroAmerican political passion to rise over worsening terms of trade for goods from the undeveloped countries?" Not least, where was "the Afro-American state," "provisional government or any institution which can claim or force a national unity"? Adolph Reed, Jr., "The Current Status of the Black Movement," in Singham, ed., Non-Aligned Movement, pp. 212-216, quotes on 212 and 215. The essay as submitted was titled "The Erective Flea Doing a Backstroke Beneath a Drawbridge, Shouting 'Raise the Bridge!': Non-Alignment as an Issue in Black American Politics." 
historiography. Not least, they remind us of the continuities in racial identification among leaders in Washington and London who had still not quite got the hang of substituting North Atlantic community for Anglo Saxon people. While successful, convincing, and innovative in many respects, when it comes to Bandung the new "international" or "transnational" social and cultural historians have done little more than report what White and Black Americans, reporters, and fellow travelers, mostly on the sidelines of these events, imagined and wrote about the darker nations, and so they missed a tremendous opportunity to advance our knowledge about Bandung and its rivals. ${ }^{12}$ These projects were unfolding not just as part of the global Cold War but also of a complex, post independence politics across three continents or what one of the remarkable tacticians of that moment, George Padmore, called the transfer of power. ${ }^{13}$

The idea that the First Asian-African Conference in Bandung in 1955 in which the majority of 29 states were outspokenly aligned-the number of "neutralists" varies from 3 to 10 according to how one counts fellow travelers and communists-was a conference of the nonaligned states or that the nonaligned movement began there is a kind of Paul Revere's ride of our postcolonial age. Many if not most of the men representing those same dependent states would likely have responded to claims of a unity or alliance of color with blank or uncomprehending stares or else would have smiled politely and moved on. Getting at race--or better racialization—at Bandung requires analysis of the discourse of and identification in terms of "civilizations" different from those of the West, as the speeches and resolutions repeatedly asserted, which Itty Abraham and

${ }^{12}$ For all the professed differences with "traditional" political and diplomatic histories of the Cold War, the new "international" social and cultural history often fails in precisely the same way to get beyond the single dimension treatments of actors and institutions elsewhere, in Cairo, say. Starkly inferior to accounts of the American "side" and drawn so faithfully from the same side's characterizations of one or another "radical," "nationalist," "moderate" (or as a cultural historian might write, "client," "independent," and the older "comprador), defined in terms of that agent's or institution's support for or dissent from the preferences of Washington (or Newark, NJ). If anything, the accounts of Nasser, Nehru, and others at Bandung are even less convincing than those by the diplomatic historians, even while the journalists, musicians, and novelists are made to come alive.

${ }^{13}$ There is no way around the fact that political scientists and areas studies have produced voluminous work on these matters, which go mostly unreferenced. Instead the domains or arenas of state building, including, for lack of a better term, the imperial ambitions of one or another would be regional hegemon, remain terra incognita, and analyses typically operate, mostly unconvincingly, at the level of western neoimperialism and the forces either resisting or assisting the new and unequal global order. 
Kyle Haddad-Fonda have explored most recently. ${ }^{14}$ What I do here is try to get the politics (not least the line-ups) right.

I first sample the range of recent solidarity journalism, diplomat's self-fashioning, and claims by diplomatic and postcolonial historians and theorists about Bandung, literally all of which are grounded not in scholarship but in popular memory. A technical literature exists but its arguments have never been confronted and wrestled with. One defensible thesis about why so many continue to believe that Bandung gave rise to Belgrade is that most hopelessly confuse the two, as we will see, in terms of who were there and what was argued. Any effort to finally write a plausible, scholarly version of the Bandung origins of Non-Alignment will need to start with the counterfactual: If no Bandung then no Belgrade? (section I) The turn to writing about those for whom Bandung represented the hope (or threat) of color's emergence as a "global identity" ${ }^{15}$ only adds additional layers of confusion about the identifications, affiliations, and choices of those in the committees and plenary sessions (II and III). I next consider some key dimensions of the politics (and ideas) of Bandung versus Belgrade and Pan-African versus Afro-Asian solidarity organizing as part of the process of state building and intervention. Presuming on good grounds that those who write about the Non-Aligned Movement today don't actually know how the movement's members “joined” (they didn't, they were chosen, much like some readers used to choose sides in pickup baseball games, only a lot more states than players, especially African ones, were left to go find something else to do), I turn briefly to Nasser's efforts to dominate this institution, Nehru's efforts to stop him, and the beginning of the latter's withdrawal from a movement that was cresting before it ever had a chance to gather (IV). I then turn to Nasser's rivalry with Nkrumah for domination over the newly independent countries of Africa, and the assistance the latter obtained from the Asian state that the Middle Eastern ones kept out of

\footnotetext{
${ }^{14}$ Abraham, From Bandung to NAM, and Kyle Haddad-Fonda, "The Anti-Imperialist Tradition and the Development of Sino-Arab Relations, 1955-1958, senior thesis, Departments of History and Near Eastern Languages and Civilizations, Harvard, 2009. This remarkable work draws on work in both Chinese and Arabic sources.

${ }^{15}$ Cynthia Young discussing Du Bois's reading of Bandung and by extension the "ideals animating a diverse group of US-based intellectuals, artists, and activists mobilizing in the 1960s and 1970s." Soul Power: Culture, Radicalism, and the Making of a US Third World Left (Durham: Duke University Press, 2006), p. 2.
} 
Bandung, that is, Israel (V). I conclude with some implications of the turn from solidarity to scholarship (VI).

\section{Q: Which of The Following Non-Aligned Leaders of the Darker Races Met at Bandung?}

(a) Tito

(b) Nkrumah

(c) Castro

(d) None of the Above

Political scientist George McTurnan Kahin (1918-2000) is best known as an early critic of the Vietnam War who as a new assistant professor served as executive director of Cornell's Southeast Asia program and founded its Modern Indonesia Project in 1954. He happened to be Indonesia on a research leave when the five Colombo Powers-Indonesia, India, Burma, Ceylon, and Pakistan—hosted the Asian-African Conference in Bandung in April $1955 .{ }^{16}$ Indonesia's Sukarno, a gifted public speaker, opened the meeting with a speech that included the lines quoted above from Henry Wadsworth Longfellow's Midnight Ride of Paul Revere, a surprising oratorical turn that American diplomats said they had inspired. ${ }^{17}$ Kahin is one of the never mentioned two dozen or so American men and women who wandered the halls and hotels that week along side Richard Wright, Carl Rowan, Max Yergan, and Adam Clayton Powell, Jr., and Kahin knew a lot more than most about Asia. ${ }^{18}$

${ }^{16}$ See Kahin's obituary in Cornell News, http://www.news.cornell.edu/releases/Feb00/G.McT.Kahin.Obit.html, accessed November 27, 2008. Kahin was arrested and expelled from the country by the Dutch colonial authorities while he was pursuing his Ph.D. research in 1948-1949, which he published as Nationalism and Revolution in Indonesia (Cornell 1951). According to his student and friend Dan Lev, the US government also blocked his passport for a while around this time.

17 "This touch came from a hint which I dropped to Abdulgcsi [presumably an error in decoding referring to Roeslan Abdulghani] several weeks ago. Secretary General greeted me this morning at opening session with enthusiastic remark to effect that "It's included."' Jakarta to State, 1869, April 18, 1955, General Records of the Department of State, Record Group 59, 670.901/4-1555, US National Archives, College Park, MD [hereafter cited as RG 59 with filing information].

${ }^{18}$ China scholar Arthur Doak Barnett, then based in Hong Kong, was another knowledgeable observer at the conference, and he wrote four detailed dispatches for the American Universities Field Staff, although these have not been referenced before to my knowledge. The State Department's Office of Intelligence Research compiled and circulated all four in summer. See 
Kahin decided to write a book on the conference, as did Richard Wright. Unlike the latter, Kahin traveled to Cairo, Delhi, Karachi, and Rangoon to follow up with key delegates, including Nehru's main advisor, Krishna Menon, and a thirty-seven year old Egyptian colonel, Gamal Abdel Nasser, the new prime minister who made his debut on the international stage at Bandung, his second trip abroad in his life following his pilgrimage to Saudi Arabia a year earlier. Back in Ithaca a few months later with a bundle of press clippings and other source materials, Kahin produced the first and still essential scholarly work on Bandung. ${ }^{19}$ Asian-African Conference. Bandung, Indonesia, April 1955 appeared a month or two behind pamphlets by a conference administrator and head of the Indian Institute for World Affairs, Angadipuram Appadorai, and by an Evanston, Illinois Unitarian minister, peace activist, and American Committee on Africa board member, Homer Jack, who attended on journalist credentials, and about the same time as Wright's Color Curtain. A few months later, the conference's crusading Filipino anticommunist, Carlos Romulo, came out with The Meaning of Bandung. ${ }^{20}$ It would take another 50 years before another book on Bandung itself appeared.

Kahin's conclusions hold up well against what has since been revealed in declassified records from the 1950s. Nehru in particular was reluctant to hold such a meeting. What led the five leaders of Asia to agree to go ahead ultimately was the fear that increasing US-China tensions might lead to a new major war in the region, which inspired the decision to invite the People's Republic, a state that the US had prevented from taking its seat at the UN. ${ }^{21}$ Kahin

Report on Bandung by A. Doak Barnett, External Research Paper Number 124, August 31, 1955, Folder 637, Box 84, Series-Washington, DC, Record Group 4, Nelson A Rockefeller Papers (NAR Papers), Rockefeller Family Archives, Rockefeller Archive Center, Tarrytown, New York [hereafter RAC with filing information]/

${ }^{19}$ His wife, Audrey, allowed me to use Kahin's research collection on Bandung in 2006 while she was still working through his career's worth of papers.

${ }^{20}$ See Appadorai, Titles, Homer Jack, Bandung: An On-The-Spot Description of the Asian-African Conference (Chicago: Toward Freedom, 1956), Carlos Romulo, The Meaning of Bandung (Chapel Hill: University of North Carolina Press, 1956), and Richard Wright...

${ }^{21}$ The new literature on these matters in this period is enormous but start with Thomas Christensen, Useful Adversaries: Grand Strategy, Domestic Mobilization, and Sino-American Conflict, 1947-1958 (Princeton: Princeton University Press, 1996), Chen Jian, Mao's China and the Cold War (Chapel Hill, NC: University of North Carolina Press, 2001), and Gong Li, "Tension across the Taiwan Strait in the 1950s: Chinese Strategy and Tactics," in Robert Ross and Jiang 
judged the event a success, "modest, it is true, but more than most statesmen had expected." On the one hand, Zhou Enlai's performance had allayed the suspicions of many delegates, who were meeting for the first time with the communist leader from a country tied to the USSR by treaty. On the other hand, a kind of "moral restraint against Chinese aggression" had emerged (they hoped). Other accounts, including Richard Wright's and Doak Barnett's, back Kahin up on the masterful diplomacy of the Chinese premier who used the conference to call for a negotiated solution to the Formosa crisis. In other words, Bandung played a "significant... if relatively minor" role in the first, brief post-Stalin "détente between the Communist and non-Communist worlds," as Kahin envisioned it. ${ }^{22}$

Since not all delegations were necessarily aware of let alone compelled by the motives of the organizers, there is a second (in Kahin's view secondary) way in which to gauge the success of the conference, namely in terms of "areas of agreement" among the conferees. ${ }^{23}$ What united the 29 delegations, as opposed to the 5 organizers only, judging from the final resolutions, was an opposition to colonialism and white supremacy or what was referred to as "racialism." Throughout that week, delegates had condemned apartheid in South Africa on these grounds. ${ }^{24}$ Delegates also agreed that those of them still excluded from the UN-Cambodia, Ceylon, Japan, Jordan, Libya, Nepal and a "unified Vietnam"-were entitled to membership, and that while they affirmed the legitimacy of the UN they wanted a greater voice in the Security Council. They collectively endorsed the UN Universal Declaration of Human Rights, pressed for general disarmament, and called for greater economic cooperation and cultural exchanges among their countries and regions.

Changbin, eds, Re-examining the Cold War: US-China Diplomacy, 1954-1973 (Cambridge, MA: Harvard University Asia Center, 2001).

${ }^{22}$ Kahin, Asian-African Conference, pp. 1-2, 4-5.

${ }^{23}$ Ibid., p. 32.

${ }^{24}$ See the account by Homer Jack for the significance of the conference from an African as opposed to an Asian perspective, which doesn't bother to reference the questions of defense pacts and peaceful coexistence, but does reference the paternalism of Nehru in a conference where "Africa was very much a junior partner." Thus, it was "up to Asia to help Africa to the best of her ability." Homer Jack, "Africa at Bandung, Africa Today, 2, 2 (May-June 1955), pp. 12-13. He rehearses the point in his 1956 Bandung while noting how ideas of a rising anti-white racism there failed to conform to reality, pp, 32-33, 36. 
We might add that they also reaffirmed the right, specified in Articles 51 of the UN Charter, of a state to defend itself, "singly or collectively." The original draft articles of the United Nations had said nothing about "collective self defense," but South American delegates at the founding San Francisco conference proposed the new article to resolve the crisis over the status of the Inter-American System, an alliance-in-formation with the United States. Some at the time had thought regional defense arrangements would contravene the "universality of the jurisdiction" of the proposed UN Security Council. Egypt's representative argued for the legitimacy of the new six-member Arab League under the same Article 51 while adding that Egypt was against the kinds of alliance agreements that had been forced on his own country by Great Britain. ${ }^{25}$ The Atlantic Pact or Treaty signed in 1949 would soon follow, and Nehru argued in closed session at Bandung that there had been good grounds for founding NATO but that he objected to the extension of such arrangements to colonial territories. ${ }^{26}$ Nehru would also do much backtracking in later years in trying to square what was agreed to at Bandung with his opposition to regional defense pacts. The ambiguities reflected the unanimity rule adopted for the conference and the more enduring one (or reality) that small states feared near-by state building projects more than far away Cold War politics.

Reviewing Kahin book in the Institute of Pacific Relation's journal, Pacific Affairs, together with what he called the slighter contribution by Appadorai (that the IPR published), the Dutch anthropologist W F Wertheim opened with the prediction that the recently concluded conference would appear in future history textbooks as "one of the major events" of the mid-twentieth century, although Westerners were slow to recognize its importance. ${ }^{27}$ Howard University's Merze Tate led with the same claim in reviewing Wright's Color Curtain while tearing it apart for its

\footnotetext{
25 Joseph Kunz, "Individual and Collective Self-Defense in Article 51 of the Charter of the United Nations," American Journal of International Law, 41, 4 (October 1947), pp. 872-879.

${ }^{26}$ Kahin, Asian-African Conference, p. 30.

${ }^{27}$ Untitled Review, Pacific Affairs, 29, 3 (September 1956), pp. 272-273. W. F. (“Pak") Wertheim, who died in 1999, is described in one tribute of Holland's counterpart to George McT Kahin, a second supporter of the nationalist struggle, and the founder of Indonesian studies in Holland. See the Obituary by Herb Feith, http://insideindonesia.org/content/view/710/29/, accessed November 27, 2008.
} 
exaggerated color consciousness. ${ }^{28}$ Wertheim and Tate though got it wrong. For decades, historians have mostly ignored the Asian-African Conference, else we wouldn't find scholars echoing the solidarity movements' origin stories quite so faithfully. ${ }^{29}$ Kahin's study sits undisturbed in the stacks and off site storage facilities, and can be bought for next to nothing on line, while Wright's was reprinted in 1994, giving new life to the romance of Bandung as a gathering of all the darker and nonaligned nations and peoples that has come to substitute for knowledge of the event and the complex political conflicts and alignments that it reflected.

The mythmaking was a phenomenon first noted and brilliantly dissected decades ago by $\mathrm{G}$. $\mathrm{H}$. Jansen in the still unsurpassed 1966 postmortem on the two distinct and ultimately competing frameworks of Afro-Asia and of Nonalignment. ${ }^{30}$ Most of what continues to be written about the conference by public intellectuals, would be revivers of the "Spirit of Bandung" and professors of postcolonial studies is myth, like what was written about Paul Revere, drawing on Longfellow's romance as a source. In both cases, "facts matter little when a good story is at stake."31

In an hour's search I came up with a dozen recent examples. In 1994, then New York Times foreign correspondent Barbara Crossette remembers the "summit" wistfully, using the wrong name, "the Afro-Asian Conference." Nehru had made a specific decision to call it the AsianAfrican Conference because, as he explained at a press conference in December 1954 in Jakarta, "it is a finer way of describing it. We put Asia first because it is a smaller word, not because Asia is more important or less." In private he objected that Afro-Asian "sounded like

${ }^{28}$ Merze Tate, Journal of Negro History, 41, 3 (July 1956), 263-265. Tate had recently returned from a year in Asia on a Fulbright Grant where she had lectured across India, traveled, and continued research on the imperial expansion in the Pacific.

${ }^{29}$ As Antoinette Burton, Augusto Spiritu, and Fanon Che Wilkins write in an introductory piece, "The Fate of Nationalisms in the Age of Bandung," when they submitted a panel proposal on Bandung to the 2005 meeting of the American Historical Association, they were told that no one on the committee had heard of it. Radical History Review 95 (Spring 2006), pp. 145-148: 145.

${ }^{30}$ Jansen, Afro-Asia. Philip Holden returns to this critique of the mythmaking in his "Imagined Individuals: National Autobiography and Postcolonial Self-Fashioning, Asia Research Institute, Working Paper Series, No 13, October 2003.

${ }^{31}$ Ray Raphael, Founding Myths: Stories That Hide Our Patriotic Past (New York: New Press, 2004), p. 23. 
aphrodisiac." ${ }^{32}$ But Crossette also included then Gold Coast prime minister Kwame Nkrumah among the summiteers. ${ }^{33}$

In 2002, Philippine Foreign Secretary Blas Ople called for a second Bandung Conference to follow on the first, the one that brought together, among others, Castro, Tito, and Nkrumah. ${ }^{34}$ Ward Churchill singled out Mao Zedung's contribution to the event the very next year. ${ }^{35}$ But the hazy recollections of what transpired at Bandung picked up steam as post-Third World States actually fulfilled Ople's dream, meeting at a new Nonaligned Summit in Havana in October 2006. The one-time editor of Muhammad Speaks, Askia Muhammad, filed a report from Cuba where Kofi Annan had evoked Nkrumah as a founding figure of the movement at Bandung. Muhammad includes him together with Nehru, Tito, Sukarno, and Nasser, the five stalwarts he imagines is who was referred to in what he calls "the Initiative of Five."36 Chilean journalist Alejandro Kirk, filing from Havana for Terraviva, remembers Bandung too as the place in 1955 where Tito, Nkrumah, and Ho Chi Minh first got together. ${ }^{37}$ Egyptian journalist Galal Nasser, in a January 2007 column recalling the ideals that drove an earlier Egyptian generation, has his hero, Gamal Abd al-Nasser leading a campaign that culminates in Bandung, where equally idealistic leaders such as Tito, Nkrumah, and Jomo Kenyatta "joined....in a call for liberation and independence that turned the Third World into a counterbalance of both East and West." ${ }^{38}$ Two months later, in a

${ }^{32}$ See Jakarta to State, telegram 1590, March 24, 1955, Record Group 59, State Department Central Files, 1955-1959, 670.901/3-2455.

33 "The 'Third World' Is Dead, But Spirits Linger, NYT, November 13, 1994, http://query.nytimes.com/gst/fullpage.html?res=9905E2DE1731F930A25752C1A962958260, accessed November 28, 2008.

${ }^{34}$ Holden, "Imagined Individuals," p. 1.

${ }^{35}$ Ward Churchill, On the Justice of Roosting Chickens (City? A.K Press, 2003), p. 286. Sadly, so did Don Peretz in The Middle East Today (New York: Praeger, 1994), p. 148.

36 "Non-Aligned Movement Summit Attended by U.S. Foes and Allies [just like at Bandung!], FinalCall.com News, October 13, 2006, http://www.finalcall.com/artman/publish/article 2983.shtml, accessed November 28, 2008.

37 "Renovation in NAM: The Winding Road of the Non-Aligned," Asia Media Forum, Posted September 13, 2006, http://www.theasiamediaforum.org/node/522, accessed on November 28, 2008.

38 "The Generation Gap," Ahram Weekly, January 18-24, 2007, http://weekly.ahram.org.eg/2007/828/op33.htm, accessed November 28, 2008. 
posting on the world wide web, the deputy editorial page editor at the Jerusalem Post, Eliot Yager, misdates the conference to 1956, and says it is where Nkrumah "met and exchanged ideas with Third World luminaries" including Ho Chi Minh. ${ }^{39}$ The London School of Economics and fraternal organizations sponsored a conference in Serbia on the fiftieth anniversary of the conference, inviting participants to reflect anew on a meeting that had Nkrumah meeting other Third World Leaders. ${ }^{40}$ Most recently, Rob Burton, an English professor at California State University-Chico, includes Nkrumah in his list of "high profile delegations," but calls him the leader of Sudan, a country he says "had been recently freed of colonial domination," although Sudan was then still a joint condominium of the Egyptians and the British. ${ }^{41}$

Nasser, fearing for his fate at home, was a late-deciding attendee who received his main briefing on the upcoming conference from the CIA. ${ }^{42}$ None of the hosts knew much about him. Nehru, who was suspicious of Nasser's close ties to the Americans and who had read his Philosophy of the Revolution ("a pamphlet") did not think much of his intellect. ${ }^{43}$ Nasser was, needless to say, not one of the conference's organizers, let alone a neutralist visionary. When quizzed by journalists in New Delhi about his views on Nehru's five famous principles of

${ }^{39}$ The ironically titled post is "Taking Ghana For Granted," The Jager File, http://elliotjager.com/2007/03/taking-ghana-for-granted.html, accessed November 28, 2008.

${ }^{40}$ http://www.Ise.ac.uk/collections/IDEAS/2005\%20CWSC\%20Events.htm, accessed December $15,2008$.

${ }^{41}$ See Rob Burton, "The Enduring Legacies of Bandung, Non-Alignment, and Richard Wright," 2nd Global Conference: Multiculturalism, Conflict, and Belonging, September 2008, Mansfield College, Oxford. He also describes Nasser of Egypt as among the attendees on the CIA's "most wanted list" at a time when the CIA had closer ties to Nasser than to any other Arab leader, and was closer to him than the ambassador, as the quotation below hints at. See Robert Vitalis, When Capitalists Collide: Business Conflict and the End of Empire in Egypt (Berkeley: University of California Press, 1995).

42 So the US ambassador reported back to Washington after seeing Nasser on the eve of his Asia tour, "extremely thorough coverage and briefing by another agency reaching him personally made it unnecessary that I do other than support what had been given hm." Cairo to State, 1483, April 5, 1955, RG 59, 670.901/4-555.

${ }^{43}$ Ginat, Neutralism, p. 94, drawing on correspondence between Nehru and the Indian ambassador in Cairo. 
coexistence, he responded, "what are they?" ${ }^{44}$ Nehru, who was a neutralist, had, as I said, initially objected to the holding of the meeting. None of the other men named above had set foot in Bandung that April. Nkrumah, leader of the Gold Coast, not Sudan, and anxious not to do anything to upset the timetable for independence, sent his friend Kojo Botsio as "observer" rather than as a full-fledged delegate, with instructions to keep his head down. ${ }^{45}$ Kenyatta wasn't invited. Nor was Tito. Ho's close comrade and prime minister of the Democratic Republic of Vietnam, Pham Van Dong, led the North's delegation. And last time I looked Cuba wasn't an Asian-African state nor was it one governed by Castro, the guerilla, interned at the Isle of Pines Prison at the time of the Bandung meeting.

A reader might object that I have stacked the deck with writers, journalists, and literature professors, yet even historians get this one wrong or, better, don't even question what has become a matter of common sense. Partha Chaterjee's recent effort to revisit the idea of empire imagines a Bandung conference where Nkrumah and Ho took part. ${ }^{46}$ The prolific Australian Asian studies scholar, Mark T Berger, wrote the entry on Bandung for the Encyclopedia of the Developing World, which also includes Nkrumah and Tito among the attendees. ${ }^{47}$ The University of Colorado professor of modern Egyptian history, James Jankowski, and the Clark University historian of the cold war in the Middle East, Doug Little both write that Nasser was with Tito in

44 "A Place in the Sun," Time, Monday, April 25, 1955, available on line at http://www.time.com/time/magazine/article/0,9171,861356-2,00.html, accessed December 15, 2008.

${ }^{45}$ Commonwealth Relations Office to Various High Commissioners, No. 89, March 28, 1955, DO 35/4665, The National Archives of Great Britain, Kew [hereafter cited as TNA with filing information]; Memorandum of Conversation, Report on Bandung by Adam Clayton Powell, Jr., May 9, 1955, RG 59, 670.901/5-955.

${ }^{46}$ Partha Chatterjee, "Empire and Nation Revisited: 50 Years After Bandung," Inter-Asia Cultural Studies, 6, 4 (2005): 487-496. The power of the myth's hold over us is only made more clear when we consider that Chatterjee used and quoted from documents written at the time. Consider as well Brantly Womack, the professor of politics and specialist in Asian international relations who named China one of the five sponsoring countries (!) of Bandung in China and Vietnam (Cambridge: Cambridge University Press, 2006), p. 169. Conservative historian Arthur Herman places Nkumah at Bandung in Idea of Decline in Western History (New York: Free Press, 1997), p. 218

47 "Bandung Conference (1955)," in Thomas M. Leonard, ed., Encyclopedia of the Developing World, Volume 1, A-E (London: Routledge, 2005), pp. 139-140. 
Bandung. ${ }^{48}$ And Robert J. C. Young, in the weighty Postocolonialism: An Introduction (2001), includes—well you can guess by now—Nkumah and "odd-man-out geographically, though not geopolitically, Tito." ${ }^{49}$ Compounding the nicely executed standard error with a wholly original one, Young says that the conferees "set up the institutional basis of what would become the Movement of Non-Aligned Countries, and while an institution means different things to different people, Nehru and others acted to prevent the creation of any kind of permanent structure or organization, and various would be conveners of a follow up meeting-Nasser, Sukarno, Pakistan's Zulfikar Ali Bhutto, Algeria's Ben Bella-failed repeatedly over the next ten years to bring Asian and African states together once more, the Egyptians perhaps going so far as to bomb a conference site in Algiers to prevent organizers from meeting. ${ }^{50}$

Little wonder that those who hold up the banner of Bandung today prefer to imagine that the sometime rival, sometime simply orthogonal convocations track the evolution of a "movement": The meeting of Afro-Asian, including Russian, peoples, not states, at Cairo in 1957, which led to the creation of the Afro Asian Peoples Solidarity Organization with backing by the Soviets, the meeting of Independent African States in 1958, and of Pan-Africanists in Accra in 1959, of NonAligned Heads of States or Governments in 1961, the one that is routinely confused with Bandung in most of the above examples. Future scholars might want to do more to recognize, distance themselves from, and test the assumptions of the solidarity groups (and no doubt Indian

48 James Jankowski, Nasser's Egypt, Arab Nationalism and the United Arab Republic (Boulder: Lynne Reinner, 2001), p. 65. Douglas Little, American Orientalism (New York: X), p. 168. In addition we can add the self-styled Middle East expert, Trevor Mostyn, reviewing a biography of Nasser in the Times Literary Supplement, January 28, 2005, available on line at http://www.trevormostyn.com/page17.htm, accessed December 15, 2008.

${ }^{49}$ He goes on to explain the logic motivating Tito to attend (p. 191). More amazing still, he does so while citing all the 1955 and 1956 books on the conference!

${ }^{50}$ Nehru had made clear in a press conference before the meeting that he "did not foresee establishment any permanent body," as the Djakarta embassy reported back to State, 1833, April 17, USRG 59, 670.901/14.1755, Box 2669, USNA. As Jamie Mackie writes, pointedly, "no organizational arrangements or mechanisms had been set up (Nehru regarded this as superfluous), and no action was taken to do so." Bandung 1955: Non-Alignment and Afro-Asian Solidarity (Singapore: Didier Millet, 2005), pp. 109-100, and passim. Also See Colin Legum, Bandung, Cairo, And Accra: Report on the First Conference of Independent African States (London: Africa Bereau, 1958); Franklin Weinstein, "The Second Asian-African Conference: Preliminary Bouts," Asian Survey, 5,7 (July 1965), pp. 359-373, and Guy Pauker, "The Rise and Fall of Afro-Asian Solidarity," Asian Survey 5, 9 (September 1965), pp. 425-432. 
and Egyptian school books), by answering the following questions: If Bandung is understood most fundamentally as a launching point for the Nonaligned Movement, then why, once launched, did the original conveners of Bandung continue efforts to reassemble? Minimally, it means that the concerns of the two groupings or leaderships did not completely overlap, another point carefully, clearly, and repeatedly made by virtually all scholars at the time. What has happened in the meantime $?^{51}$

\section{Color Curtain}

One, the most recent problem, is that the new social and cultural historians chose to leave the political science of the 1950s, '60s, and '70s behind (or never thought to look for it) while turning to the Chicago Defender, Pittsburgh Courier, Baltimore Afro-American and the Color Curtain to revive the accounts invariably found there of Bandung as a meeting of the darker races. Knowing what the reporters wrote and what inspired African American internationalism in a dismal time in the US is important but that work at times confuses the world views of North Americans with, well, views of the world as a whole. And they can get carried away. So, Paul Gorden Lauren believes, much like Malcolm X did, that the organizers "deliberately refused to invite any white power," which is not true, as Wright himself documents (p. 88). He also describes Nehru and Nasser, among others, speaking "movingly about their shared experience due to the black, brown, and yellow color of their skins.. ${ }^{52}$

Nehru declined the opportunity to address the conference in open session but in his summing up on the last day not a word about race appears. Nasser gave three addresses. None of them uses the word race or color let alone speaks of race's effect on him or on Egyptians or on Middle Eastern peoples. There is virtually nothing in any of the addresses at Bandung, including those by Yilma Deressa of Ethiopia, in Botsio's short remarks, or by Ismail al-Azhahri of Sudan

${ }^{51}$ Peter Lyon, writing in 1963 was another who got it right. Neutralism existed as one politically tendency before and during the conference but was in no way "fully synonymous" with the states that met and the projects they pursued at Bandung. See his Neutralism (Leicster: Leicster University Press, 1963), p 48.

${ }^{52}$ Paul Gordon Lauren, Power and Prejudice: The Politics and Diplomacy of Racial Discrimination, Second Edition (Boulder: Westview, 1996), pp. 223-224. 
that remotely resembles Lauren's account about what went on in the conference hall. ${ }^{53}$ The one serious exception is the long address by Romulo, who indeed spoke passionately about the effect of race on him, other Filipinos and other victims of colonialism, and just as important, warned of new forms of racialism threatening to erupt in many of the newly independent countries.

It is as if the new historians never read beyond the line in the official transcript where Sukarno welcomes "the first intercontinental conference of colored peoples in the history of mankind," a statement that led to objections by many of the delegates. Nasser, Faisal ibn Abd alAziz, and the other Arabs hardly identified as such. Nonetheless, Melani Mcalister in Epic Encounters holds up Nasser in particular at Bandung both for leading the misidentified twentynine state nonaligned movement but also for representing (for whom other than those in Harlem?) a new "global racial consciousness." ${ }^{54}$ The Lebanese ally of the US, Charles Malik, in a debriefing with Dulles, expressed his real fears that the colored races could very well be coming together in a way that threatened the West's interests, of which he and his people were a part. ${ }^{55}$ The Turkish delegates complained about the repeated references by the North Americans there to Bandung as a meeting of colored races since it by (self) definition left Turkey out. ${ }^{56}$ Finally, consider the book published by the Institute of Asian-African Relations on the first anniversary of the Bandung Conference, which explains that India, Iran, and the rest of the Middle East are peopled by

${ }^{53}$ Azhari would later write that one important consequence of the conference "is that those colored races which had long been living at the borderline turn today into a great force whose say comes out like thunder, and they have proved their ability to direct this formidable force towards good and right and not towards evil and aggression." "Sudanese Delegates' Impressions and Views on Bandung Conference," Sudan Weekly News, Special Supplement, Sudan in Bandung Conference, Khartoum, n.d. but probably Summer 1955, p. 32. The accounts by three other delegates, Mubarak Zaroug, (Minister of Communications), Hassan Awadalla (Minister of Agriculture), and Khalifa Abbas (Deputy Under Secretary of External Affairs) also do not invoke any notion of particular race consciousness or identity.

${ }^{54}$ See p. 90 . She goes on to misidentify the 1957 Afro-Asian Solidarity Conference as the "followup event to Bandung," and claims it is where, as host, Nasser replaced Nehru as leader of the movement (p. 91). Nasser never stepped foot inside the meeting at any point that week. Legum called it a mystery. The US embassy read it as a function of the too visible role of the communists there, by whom they generally meant the fellow traveler, Khaled Mohieddin, who headed it.

${ }^{55}$ See Memorandum of Conversation, May 5, 1955, Report on Bandung, RG 59, 670.901/5-555.

${ }^{56}$ Observation made in the report produced by an agent of the Standard Vacuum Oil Company assigned to cover Bandung, author omitted in the copy given to the State Department and dated May 10, 1955, enclosed in Tucker to Hodge, August 15, 1955, STANVAC Special report on Bandung Afro-Asian Conference, RG 59, 670.901/8-1555. 
"branches of the White Man," just different from the branch that subjugated the Black and Yellow Man. $^{57}$

Brenda Plummer explains the origins of Bandung as the response of "a group of African, Middle Eastern, and Asian neutralists" to bullying by the US and USSR, calling for a "May 1955 conference of nonaligned states." I count three errors of fact in that one sentence alone. The result was, she says, a rejection of Cold War Era treaty making." ${ }^{\text {58 }}$ That is the fourth. Penny Von Eschen relies in turn on Lauren in her account of the conference as the "most important and influential of several attempts" to organize around nonalignment, and she adopts the reading of the run up to the event then popular in Harlem, Washington, London and Canberra, but far removed from accounts in Cairo, Beijing, Colombo or Delhi. ${ }^{59}$ Meanwhile, Kevin Gaines relies on Plummer, writing that Bandung launched nonalignment "as a global political formation." 60

Let me be clear that I love each of the books just referenced. The point is to solve the problem that these errors appear to pose, driven generally by the project itself of emphasizing and at times adopting the particular perspective of what comes to be called African-American or Black internationalism. Justin Hart is another scholar who emphasizes the same particularistic point of view of much of this literature. ${ }^{61}$ There are also some other key works by diplomatic historians that advance arguments, syntheses and revisions that have little in common with the Bandung-as-birth-of the-non-aligned-movement school, while the evidence they uncover offers scant support to the idea. University of Auckland professor Nicholas Tarling led the way in 1992 with an illuminating account of British policy, and three new US-focused studies followed by Cary

${ }^{57}$ Suniti Kumar Chatterji, "Black Africa and the World," Peaceful Coexistence, Institute of AsianAfrican Relations, Calcutta, 1956.

${ }^{58}$ Brenda Plummer, Rising Wind: Black Americans and U.S. Foreign Affairs, 1935-1960 (Chapel Hill: University of North Carolina Press, 1996), p. 247.

${ }^{59}$ Penny Von Eschen, Race Against Empire: Black Americans and Anticolonialism, 1937-1957 (Ithaca: Cornell University Press, 1997), pp. 168-169.

${ }^{60}$ Kevin Gaines, American Africans in Ghana: Black Expatriates and the Civil Rights Era (Chapel Hill: University of North Carolina Press, 2006), p. 71.

61 Justin Hart, "Making Democracy Safe for the World: Race, Propaganda, and the Transformation of United States Foreign Policy During World War II, Pacific Historical Review 73, 1 (Feb 2004), pp. 49-84: 53, n. 4. 
Fraser in 2003, Matthew Jones in 2005, and Jason Parker in 2006. ${ }^{62}$ Fraser, Jones, and Parker also all locate themselves within the new "race in the making of US foreign policy" current. ${ }^{63}$

\section{III “The Atlantic Charter: It Means Dark Races Too" 64}

There are two steps we can take toward a better understanding of the politics of the Asian African Conference and its connection to the proliferating set of meetings, conferences, and summits that grew in parallel with the increase in newly-independent countries, most in Africa, after 1960 . The first step is the easy one, and that is to recognize that the versions found in the books referenced above are all mirror images of the ones conjured up by the US State Department and British Foreign Office. The darker races had gathered at Bandung under the

${ }^{62}$ Nicolas Tarling, "'Ah-Ah': Britain and the Bandung Conference of 1955," Journal of Southeast Asian Studies 23, 1 (March 1992): 74-111; Cary Fraser, "An American Dilemma: Race and Realpolitik in the American Response to the Bandung Conference, 1955," in Brenda Plummer, ed., Window On Freedom: Race, Civil Rights, and Foreign Affairs, 1945-1988 (Chapel Hill: University of North Carolina Press, 2003), pp. 115-140; Matthew Jones, "A "Segregated" Asia?: Race, the Bandung Conference and Pan-Asianist Fears in American Thought and Policy, 19541955," Diplomatic History, 29, 5 (November 2005), pp. 841-868; and Jason Parker, "Cold War II: The Eisenhower Administration, the Bandung Conference, and the Reperiodization of the Postwar Era," Diplomatic History, 30, 5 (November 2006), pp. 1-26.

${ }^{63}$ Again, though, they are better and richer on the American and British sides, from imperious secretaries of state to crusading Harlem congressmen, than they are on the states and their agents who officially participated in the conference. Fraser and Parker have written on the Caribbean. Jones does not specialize on any of the states attending the conference. The point is not that they need to do so, but that we are missing scholarship that does, and as a result the old stories go uncorrected and unrevised. Read any of these side by side with Kahin for a sense of what we are still missing in the newest histories, and consider two new and important accounts of the participation by the Japanese delegation by Kweku Ampiah, of Chinese policy by Shu Guang Zhang, and of Egypt's bilateral relationship begun at Bandung by Haddad-Fonda as models for future work in the unlikely event that the authoritarian countries ever open up their archives. Kweku Ampiah, The Political and Moral Imperatives of the Bandung Conference of 1955: The Reactions of the US, UK and Japan (Kent: Global Oriental, 2007) and Shu Guang Zhang, "Constructing 'Peaceful Coexistence': China's Diplomacy Toward the Geneva Conferences, 1954-55, Cold War History, 7, 4 (November 2007), pp. 509-528. Ampu is the exception to my rule of new work that is not animated (haunted) by the Bandung spirit. He is, and in stark contrast to his careful account of policies, the defense of the idea of a movement's birth in April 1955 is asserted rather than demonstrated using the same methods deployed in the rest of the study.

${ }^{64}$ Headline of the Labor Party's newspaper following Deputy Prime Minister Clement Attlee's appearance before the West African Students' Union following the Allies August 1941 issuance of the Atlantic Charter that promised self-determination to all peoples. Quoted in Kenneth Robert Janken, Rayford W. Logan and the Dilemma of the African-American Intellectual (Amherst: University of Massachusetts Press, 1993), p. 168. 
umbrella of nonalignment but it is something to be celebrated rather than condemned for the positive rather than negative effects, vague as these might be, on world order.

In the six months or so before the Colombo powers agreed to hold the Asian-African conference, and as they negotiated the list of invitees, the functionaries of the Eisenhower administration let their fears run wild. They were haunted by what H.W. Brands describes as-but never critically dissects nor distances himself from— "the specter of neutralism." ${ }^{\circ 5}$ They were also haunted by the specter of race, but Brands is like many others predictably silent about the coarse and dismissive treatments of various leaders and peoples that fill the declassified dispatches, telegrams, and memoranda of conversations, which as I said is just one reason to be thankful for all the great work on racism and foreign policy that is being done.

A few at the conference-Sukarno, Nehru, and Sihanouk—presented variants on Dulles's dreaded doctrine but it was only one of a number of orientations on offer and it would be a year or two before Egypt's leaders declared themselves full followers of positive neutralism and nonalignment too-in what Leonard Binder soon called a Bismarkian or Prussian expansionist project. ${ }^{66}$ By then, however, China had reaffirmed its commitment to the unity of the Communist bloc and launched a sustained ideological attack on Tito, following with a more deadly kind of war with the erstwhile peacefully coexisting India in 1962. Nehru would secure emergency arms from the US and its allies, as his comrades in the so-called nonaligned movement opted instead not to alienate their own backers China, the USSR or both. ${ }^{67}$ Matters only grew more treacherous year by year for anyone trying to keep various peace or disarmament, nonalignment, and solidarity projects going, and the truth is that a few years after the world's first conference of a peculiar

${ }^{65}$ H.W. Brands, The Specter of Neutralism: The United States and the Emergence of the Third World, 1947-1960 (New York: Columbia University Press, 1989).

${ }^{66}$ For Nasser's use of the term, see Leonard Binder, "Egypt's Positive Neutrality," in Morton A. Kaplan, ed., The Revolution in World Politics (New York: John Wiley, 1962), pp. 175-191: 180. This remains until now the best discussion in English on Nasser's evolution as a neutralist. The mythmaking soon took off in earnest, with Nasser's sycophants recalling that Nehru followed Nasser's lead in Bandung, p. 188.

${ }^{67}$ A. M. Halpern, "The Chinese Communist Line on Neutralism," China Quarterly 5 (Jan-Mar, 1961), pp. 90-115. 
subset of nonaligned countries at Belgrade, where the alleged founding Asian-African Conference at Bandung was hardly talked about, scholars had turned seriously to the writing of postmortems.

Both these obsessions have histories that predate Bandung by decades. Dulles and other trans-Atlanticists combated neutralism first in the United States during the interwar years before taking on one or another imagined "Third Force" rising in Europe in the 1940s and Asia in the 1950s. Dulles at one point guessed that both Greece and Turkey would succumb. ${ }^{68}$ The fear of a revolt of the colored races, the rising tide of color, and the prospect of race war ran even deeper, evoked routinely each decade in Washington and elsewhere since 1905 when a white power was defeated by colored one in the Russo-Japanese war. ${ }^{69}$ The Royal Institute of International Affairs, which was London's equivalent of the Council on Foreign Relations, began its pitch to the Rockefeller Foundation for fresh analysis of the threat likely to replace the struggle against communism in the not to distant future by beginning with 1905 and ending with the Bandung Conference. ${ }^{70}$ And in his September 29, 1963 New York Times think piece, "Is a Race War Shaping Up?" distinguished historian Arnold Toynbee assessed the chances that whites would have to confront a world alliance of colored races—they would not, he forecast-in the course of China's bid for world domination no later than the year 2000 .

Nothing speaks to the fantastical nature of the accounts leading up to Bandung more than that none of them proved true. No delegate ever argued on the grounds that what united otherwise disparate religions, regions, and commitments represented there was something called race or color. Color was a fact for some, not for some others, but for no one was it what united them. To the contrary, many rejected the idea that color mattered. They called it racialism and warned against appealing to it as a dangerous and retrograde step. Nehru, for one, detested such talk. Meanwhile Nehru's efforts to exclude discussion of what many at Bandung saw as the

${ }^{68}$ Lyon, Neutralism, p. 38.

${ }^{69}$ Robert Vitalis, "The Graceful and Generous Liberal Gesture: Marking Racism Invisible in American International Relations," Millennium, 29, 2 (September 2000), pp. 331-356.

${ }^{70}$ See enclosure setting out the rationale of the RIIA's new Board of Studies on Race Relations (which would later become the independent Institute of Race Relations) and appointment of its director, an ex-Indian hand Philip Mason, in Folder 565, Box 65, Series 4015, Rockefeller Foundation, Record Group 1.2, RAC. 
highest stage of imperialism in the guise of the Communist Information Bureau (or Cominform), had failed. State after state refused his entreaties to denounce NATO, SEATO, and the like. His rivals would gloat over the first would be leader of the Third World's failure to dominate the conference.

The British and the American policymakers celebrated their victory at the meeting's end. But they credited it to their successful behind-the-scenes support for their "friends" rather than to their own original and wild exaggerations of the forces at play. They would continue to conjure the same increasingly intertwined twin phantoms of a third force of colored peoples suffering psychological inferiority complexes many more times in the years ahead. For instance, when his Joint Chiefs of Staff proposed the use of military force to "break" the renegade ex-client Nasser one year later in the run up to the Suez War, Eisenhower said no, fearing that it would recoil against the US. Why? Nasser "personified the emotional demands" of Egyptians and others peoples who sought not only independence but "to slap the white man down.,71

There is little gain in the fact that, now, decades later, as the postcolonial theorists return to the images that Eisenhower, Eden, Dulles, Godfrey Huggins of Rhodesia and others first used in the run up to Bandung, that they cast these in what to them appears a more positive or hopeful light.

\section{The Many Roads Leading Into and Out of Belgrade}

The second step is a harder one-it always is_-because it requires, in place of the exaggerated accounts of metropolitan power and the indistinguishable portraits of Nasser, Nehru, and Nkrumah at the head of a global formation, that we recognize the competing national statebuilding projects and regional state systemic logics as primary analytical terrain. To give one pertinent example, the better explanation for why the Asian-African Conference took place when and where it did begins not with a plan to launch the world anti-Cold War movement but to bolster Sukarno's chances in forthcoming elections. The line up of states itself is best explained by the

71 See for example Michael Cohen, Strategy and Politics in the Middle East 1954-1960: Defending the Northern Tier (London: Routledge, 2005) p. 164. 
increasing contacts and coordination among the sixteen-state voting bloc at the United Nations that had over the previous four or five years emerged to frustrate the dominance of the US and its hemispheric allies and to force increased attention on the issues of decolonization and racism. It was the performance of Egypt's ancien régime at the UN circa 1950 that led Tito to reconsider the orthodox communist views of western political dependencies years before Nasser would emerge on the scene. ${ }^{72}$ That bloc had grown to 28 states by 1958 , the largest single alignment, although Kwame Nkrumah announced that a newly independent Ghana would not actually join any group organized along interregional lines. ${ }^{73}$

Let's not fool ourselves about the work that is required to learn what we don't know about each of the relevant pre- or post-Bandung meetings. There is for example the remarkable and now all but forgotten eight-day-long Asian Relations Conference in New Delhi in 1947 with a larger list of invitees than Bandung, including Tibet, Armenia, Georgia, Turkmenistan-Nehru was then still an admirer of Russian modernization strategies-a delegation of Zionists from Palestine, and the Arab League. An additional problem is that, as Clive Christie notes, for decades scholars have done little work on "the ideas and debates that engaged the main political actors and thinkers of Southeast Asia during the nationalist and anti-colonial era. ${ }^{74}$ It may be that the varieties of nonalignment then on offer-each leader propagating a unique hybrid, "dynamic neutrality," "positive neutralism," "uncommitted," "non-engagement," and so forth—don't warrant reconsideration, with the possible exceptions of Nehru's and Tito's brands. Nkrumah is another matter. He wrote prolifically, before but especially after his overthrow and exile in 1966. This body

${ }^{72}$ See Alvin Z. Rubenstein's valuable Yugoslavia and the Non-Aligned World (Princeton: Princeton University Press), p 33. A useful summary of the early Egyptian policy positions that drew Tito's attention is found in Rami Ginat, Syria and the Doctrine of Arab Neutralism: From Independence to Dependence (Brighton: Sussex Academic Press, 2005), pp. 13-16.

73 Jan F. Triska and Howard E. Koch, Jr., Asian-African Coalition and International Organization: Third Force or Collective Impotence?" Review of Politics, 21, 2 (April 1959), pp. 417-455: 418, 423-24; Harry Howard, "The Arab-Asian States in the United Nations," Middle East Journal, 7, 3 (Summer 1953), pp. 279-292. Howard made the prescient observation that a bloc this size or larger across such a large geographic area was unlikely to evolve into a more formal kind of alliance akin to the Arab League.

${ }^{74}$ Clive J Christie, Ideology and Revolution in Southeast Asia 1900-1980: Political Ideas of the Anti-Colonial Era (Richmond: Curzon, 2001), p. xi 
of work is better understood as a species of neocolonialism theory, similar to the turn taken in Sukarno's writings and speeches in the 1960s. The only problem is that a writer provided by Israel's ambassador to Ghana wrote most of one of them, Africa Must Unite, which raises questions about the authorship of the rest. ${ }^{75}$ Nasser, mired in his own Vietnam-style war in Yemen throughout those years, replete with use of napalm and possibly mustard gas, brought out no new ghostwritten tract of his own after the 1955 Egypt's Liberation: Philosophy of the Revolution.

Nehru certainly had tried hardest to root his version, Panscheel or Five Principles of international relations (mutual respect for a state's territorial integrity, mutual non-aggression, mutual non-interference, equality and mutual benefit, peaceful co-existence), which he unveiled before Bandung and promoted during the meeting, in some alleged ancient and Indian "way of life... as old as our thought and culture. ${ }^{76}$ Ten years earlier Sukarno had unveiled his own Five Principles (pancasila) as the ideological basis of the not yet independent state. One of these, internationalism (or humanism in some older translations, together with nationalism, democracy, social justice, and belief in God), which he originally offered up as an alternative to both "vapid cosmopolitanism" and to the "inward-looking, race-oriented nationalism of Europe," served as grounding for his own later advocacy at the UN and other venues for transformation of the European-state system into a revolutionary post-colonial world order. He would also more or less jettison the idea of nonalignment and its view of a world made by the Cold War in order to promote the Third World war against neocolonialism before his overthrow in $1965 .{ }^{77}$

The real gains to a revived study of ideas may well be to recover the "indigenous" critiques of nonalignment emerging in the 1950s and $1960 \mathrm{~s} .{ }^{78}$ Consider just two of the figures that Christie includes in an increasingly self confident (if unfortunately specified) "post-anti colonial" current.

${ }^{75}$ W. Scott Thompson, Ghana's Foreign Policy 1957-1956: Diplomacy, Ideology and the New State (Princeton: Princeton University Press, 1969), p 48.

${ }^{76}$ Jansen, Afro-Asia, p. 127, 129.

${ }^{77}$ Christie, Ideology and Revolution, pp. 105, 132-134.

${ }^{78}$ See my "The End of Third Worldism in Egypt Studies," Arab Studies Journal, 4, 1 (Spring 1996), pp. 13-33. 
Soetan Sjahrir (1909-1966), founder of the Indonesian socialist party and Sukarno's first prime minister, hated the "self-glorifying and egocentric tone of anti-colonial nationalism," together with the misguided search for intrinsic Asian values to be posed against those of "the West." It was an "outdated mindset." ${ }^{79}$ Sjahrir would ultimately face arrest, jail, and death in exile. The "clearest cut case" of this trend, Christie says, is Lee Kuan Yew, prime minister of Singapore between 1959-1990. Early in his tenure, Lee Kuan Yew was arguing that "the anti-colonial mentality and its offshoot, the non-aligned world view" was itself the chief obstacle preventing countries of the region from meeting their various internal and external challenges, "shorn of alibis and ideological illusions."

What we do know is that none of the main Middle Eastern and Asian proponents of positive neutralism, nonalignment, and the like at the time of the Asian-African conference understood the idea as simply as political scientist Hans Morgenthau put it a few years later in the New York Times Magazine: "the desire not to be allied with either side in the he cold war." ${ }^{81}$ Rather, the various strains all combined ideas about alliance formation with hard-to-ground claims to crossregional solidarity, which would eventually go by the wayside, support for anti-colonial movements and, a bit later, opposition to "neocolonialism," the promotion of general disarmament and the tenets of coexistence, which, despite the claims to non-western and ancient-rootedness were mostly already part of the Charter of the United Nations.

G. H. Jansen, who wanted to salvage the nonalignment idea, peeled it back down to what he viewed as its commonsense core, a preference for exercising "an independent judgment on questions of foreign policy." Unfortunately, he lamented, it came to be "viewed incorrectly" as a product of the cold war and in opposition to it, and was saddled with various additional commitments, including an unconvincing claim about nonalignment's superior moral power. ${ }^{82}$ This defense may be the one most unconvincing claim in his treasure of a book, since what state's

${ }^{79}$ These are summary statements by Christie, Ideology and Revolution, pp. 70-72, 186.

${ }^{80}$ Ibid., pp. 187-188.

81 "Critical Look at the New Neutralism," NYT, August 27, 1961, p SM 25.

82 Jansen, Afro-Asia, p. 14. 
preference isn't for pursuit of an independent judgment on its foreign policy and what state isn't constrained at the same time by a hierarchical international order?

In June 1961, delegations from nineteen countries, eight from Africa and nine from Asia, together with a team of post Bay of Pigs Cubans, the Yugoslavians, and some Brazilian observers, met in Cairo to plan the world's first nonaligned summit. ${ }^{83}$ All the invitees represented the choices of Tito and Nasser. One of the main goals was to head off Sukarno's proposal for another Asian-African conference. A second Bandung would have reproduced the splits of 1955 and it would have been hard to involve Nasser's new, staunch European ally. Simultaneously, any conference organized on a regional basis, one of which suddenly included more than thirty independent states, would have increased the odds against Nasser's dominance given, just to mention one factor, the dissension he had sowed across Africa in the course of his intervention in the Congo crisis of the previous years.

Nasser led a set of allies that wanted a strict test of admission, what Jansen calls an exclusivist position. Nehru reluctantly agreed to participate and by the end of the meeting was viewed as an enemy of nonalignment, when really what he opposed was the continued obsession with colonialism. With virtually all of Africa either winning its independence or on the verge of doing so, colonialism was quickly fading into insignificance, and so the Cold War and some alternative to nuclear annihilation were the most important issue to be confronted in the future. Nehru pushed for and won, he thought, a more inclusive approach to participation. The delegates agreed to appoint a subcommittee to define nonalignment and to draw up a list of acceptable countries on that basis, which took two sessions and eleven hours of discussion to arrive at the following tautological definition. To qualify as nonaligned

1. A country should follow an independent policy based on peaceful co-existence and non-alignment, or should be showing a trend in favor of such a policy.

2. It should consistently have supported movements for national independence.

${ }^{83}$ There were the two or possibly three "progressive neutralists" Yugoslavia and Guinea, with Cuba posing a puzzle, "positive neutralists" Egypt, Ghana, Mali, Indonesia, and Algeria, "nonaligned" India, Burma, Ceylon, and Afghanistan, "uncommitted" Saudi Arabia, Sudan, Ethiopia, Tunisia, and Lebanon, and "disengaged" Cambodia and Laos in Jansen's recounting, Afro-Asia, p. 282. 
3. It should not be a member of multilateral alliances concluded in the context of great power conflicts.

4. If it had conceded military bases these concessions should not have been made in the context of great power conflicts.

5. If it were a member of a bi-lateral or regional defense arrangement, this should not be in the context of great power conflicts. ${ }^{84}$

The regional rivalries, clientelism, and log rolling that determined the final line up at Belgrade deserves highlighting, lest one still imagines the moment as a time when a better, more principled form of world order might have come into being. All of the countries present at the Cairo preparatory conference would attend Belgrade, although according to the terms worked out in committee, four countries—Saudi Arabia, Morocco, Ethiopia, and Yugoslavia—ought to have been excluded given the western military bases in the first three and Yugoslavia's defense treaties with NATO countries Greece and Turkey. The tiny island of Cyprus was one of only two lucky survivors among the fifteen proposed for consideration although it was still home to the base from which the British launched its invasion of Egypt in 1956. The second was Lebanon, although Egypt fought hard to exclude it on grounds that it had opposed China's admission to the UN, thus not independent enough to do Nasser's bidding. Neighboring Jordan didn't fare as well. The organizers voted against It on the grounds that it hosted US military installations, which wasn't true.

Nehru's efforts to extend invitations to additional European countries to support his more Cold War, less colonialism-focused approach foundered on the choice of Belgrade as a venue. If I read Jansen right, Sweden, Finland and Ireland all sent quiet word that invitations would have to be rejected to preserve their neutrality. The Cubans were of course allied to the Soviets, but the recent thwarted US invasion gained them a pass, and they in turn exercised a veto against a few non-favored neighbors, for instance, Costa Rica. Other Latin American states-Argentina, Chile, and Mexico-also let organizers know that invitations would be unwelcomed on the grounds that the Cubans would be there. Ultimately, Brazil, Bolivia, and Ecuador comprised the three additional not-quite full partners in the twenty nine-country meeting in Belgrade, although all of

${ }^{84}$ Jansen, Afro-Asia, p. 285. 
them should have been excluded given that they were bound to the United States in the first Cold War defense alliance, the Rio Pact.

The really important work to be done in the future is on the position of the African states and liberation movements in the real as opposed to mythical Bandung and Belgrade meetings, the latter, despite the global reimagining of it, still mostly an Asian-African affair. At Bandung, as Colin Legum put it, "the African voice was mainly Arab." ${ }^{85}$ The Liberian delegates complained bitterly of the failure to include them in the committee work on colonialism. Both Adam Clayton Powell, Jr. and the American Committee on Africa's accounts took note of the obvious less than full partnership with Asia. The Colombo powers had dropped Nigeria from the list of invitees because they hadn't a clue as to the direction and pace of decolonization there. Six years later, Nigeria still wasn't present. Despite or because of the remarkable continental transformation only one additional state, the Congo, was added to the three at Cairo-Somalia, Guinea, and Mali-out of the twenty-five self-declared nonaligned countries that had gained independence after Ghana. States were one thing, liberation movements another. Nasser and Tito extended invitations to nineteen of the latter.

\section{Spreading Enlightenment and Civilization to the Remotest Depths of the Jungle}

Transnational popular memory is just one more obstacle in the way of a full or at least less romantic account of what transpired in and around Bandung, Accra, Cairo, and Belgrade in the late 1950 s and early 1960 s.

As an Egyptian born political scientist raised in the 1950s, I am a member of a generation that was taught to believe the contention of the first Egyptian president, Gamal Abdel Nasser, that Egyptian identity was the product of 3 concentric circles: one Arab, the second was Islamic and the third was African. This was reinforced by the memory of the frequent visits by African leaders, like Kwame Nkrumah of Ghana and Modibu Keita of Mali who along with Nasser were advocates of African unity and the non-aligned movement. $^{86}$

\footnotetext{
${ }^{85}$ Legum, Bandung, Cairo and Accra, p. 5.

${ }^{86}$ Mervat Hatem, "Africa On My Mind," Middle East Studies Bulletin [publication data]. Hatem is past president of the Middle East Studies Association and a long-time professor of political science at Howard. The quotation is from the unpublished text that she graciously shared.
} 
The memory above evokes an argument in Nasser's little book that is no longer read, but that convinced many at the time that he was launching a plan of expansion echoing Hitler's, not least for the unfortunate reference to Egypt's boundaries on the one hand and its "living space" on the other. African nationalists paid particular attention to Nasser's paternalist (or worse) approach to its position astride the "Dark Continent" where the people there naturally looked to Egypt, and Nasser in return would support, with all his might, "the spread of enlightenment and civilization to the remotest depths of the jungle." 87

What of course wasn't taught then nor now is that Nkrumah and his remarkable advisor on African Affairs, the exiled Trinidadian socialist and Pan-Africanist George Padmore viewed Nasser as one of the chief obstacles in the way of African unity plans, steeling themselves against the Egyptian push deeper into the so-called "third circle" as he found his bid for hegemony in the Arab arena thwarted. ${ }^{88}$ Nasser represented a problem both in terms of his turn to the Soviets for arms, thus providing them entry into the nonaligned zone, and for his anything but peaceful coexistence with a key ally in the Bandung years, Israel. The ties with the latter country went back to pre-independence days, via another close Nkrumah ally, James Markham a Ghanaian resident in Rangoon who worked at the Anti-Colonial Bureau of the Asian Socialist Conference. Markham, distrusted by both British and US intelligence agencies, was the Gold Coast's second delegate to Bandung.

Nasser and Nkrumah waged what amounted to a "soft power" war in 1957-1959 by way of rival conferences and claims to defense of the "Bandung Spirit." In March 1957 Kwame Nkrumah announced that Accra would soon host the first Pan-African Nationalist Conference. Nkrumah's papers reveal that Padmore had begun promoting the idea of a "conference to match Bandung on

${ }^{87}$ Gamal Abdul Nasser [as rendered in the text], Egypt's Liberation: The Philosophy of the Revolution, Introduction by Dorothy Thompson (Washington, DC: Public Affairs Press, 1955), pp. 86, 110-111.

${ }^{88}$ For Padmore's views see James R. Hooker, Black Revolutionary: George Padmore's Path From Communism to Pan-Africanism (New York: Praeger, 1967), p. 135, and Zach Levey, "The Rise and Decline of a Special Relationship: Israel and Ghana, 1957-1966, African Studies Review, 46, 1 (April 2003), pp. 155-177: 158. 
an African scale with Asians as observers" back in August $1955 .^{89}$ The newly African-identified Egyptian responded with a plan of his own to host the first Afro-Asian People's Solidarity Conference. US intelligence sources considered it a communist front organization. ${ }^{90}$ Padmore saw it as an effort to subvert Nkrumah's bid for leadership on the continent. His reaction was roughly the same as Nehru's back in 1955 when the same front organizations operating then as the Asian Solidarity Committee rushed to hold its own Bandung in New Delhi a week before the Asian-African Conference. ${ }^{91}$

Nkrumah and Padmore upped the ante, rushing to hold the rival 1958 Conference of Independent African States in Accra on April 15, "in order to keep for Black Africa priority over the Afro-Asian movement in Cairo." ${ }^{92}$ The prime minister of Ghana also entered a marriage of diplomatic convenience, as even his son admits, with Fatiha Rizk, a young Egyptian Copt whom he had never met and with whom he shared no language in common. ${ }^{93}$ By the end of the year Ghana had also founded it own rival All African People's Organization, which held a founding conference in late December organized chiefly by Padmore. ${ }^{94}$ And in contrast to Cairo, Nkrumah opened the meeting up to Americans, who attended in force: Shirley Graham Du Bois, Paul Robeson, Detroit Congressman Charles Diggs, Maida Springer, political scientist Richard Sklar, then a Ford Foundation fellow, and Alphaeus Hunton, among many others. George M Houser,

${ }^{89}$ George Padmore to Kwame Nkrumah, August, 5, 1955, Folder 14, George Padmore Correspondence 1952-1957, Box 154-41, June Milne's Files, George Padmore, Kwame Nkdrumah Papers, Moorland-Spingarn Research Center, Howard University, Washington, DC.

${ }^{90}$ See Cairo to State, 1590, Dec 27, 1957, RG 59, 670.901/12-2757.

${ }^{91}$ Department of State Instruction, CA-7151, March 6, 1957, 670.901/3-657, Folder 1, Box 2671, RG 59; Jansen, Afro-Asia, pp. 251-252. The story begins with the World Peace Council, an organization founded in 1949 and funded by the Russian state. Jansen calls it a Trojan Horse showing signs of wear and tear by 1954 as it morphed into an Afro-Asian-focused project.

${ }^{92}$ See the unpublished tribute, possibly by his wife Dorothy Padmore, and written soon after his death in 1959, Folder 15-George Padmore-"George Padmore: The Theoretician of PanAfricanism, 1959," Nkrumah Papers.

${ }^{93}$ See the Nkrumah biography.; Gamal Nkrumah, "Forward Ever," Al-Ahram Weekly, 835, March 8-14, 2007, http://weekly.ahram.org.eg/2007/835/in11.htm, accessed January 28, 2009. The chief taking a bride from the other tribe strategy was an embarrassment at the time, and Nkrumah had little to do with her. See Thompson, Ghana's Foreign Policy, p 49, who calls it "one of the more bizarre alliances caused by his foreign policy."

${ }^{94}$ Gaines, American Africans, p. 107; Hooker, Black Revolutionary, p. 135. 
director of the American Committee on Africa, wrote a long report that included a section titled "Accra vs. Cairo." He took note of the intense competition between Nasser and Nkrumah, the widespread suspicion of Egypt within many of the Sub-Saharan African delegations, and the belief that when Nkrumah spoke of the fact that imperialism "may come to us yet in different guise-not necessarily from Europe," it was Nasser in particular that he had in his sights. ${ }^{95}$ The maverick Howard historian and one-time Pan-Africanist, Rayford Logan, argued much the same at the time, reporting the testimony of black African students in Cairo who suffered discrimination because of their "race and color," and describing "Nasserism" as one of the forces along with white supremacy, black supremacy, and communism propelling Africa toward a crisis. ${ }^{96}$

Israeli foreign minister Golda Meir was Ghana's guest on a state visit at the time of the conference. Padmore arranged what turned out to be a rancorous meeting for her with Algerians and others. ${ }^{97}$ Other leading figures in the Labor party government traveled to Accra as well, including Moshe Dayan, who advised on building the Ghanaian armed forces after Nkrumah turned down Nasser's offer of aid. Nothing captures the essence of the moment best than the launching of Ghana's Black Star Line, using the name of Marcus Garvey's United Negro Improvement Association's failed flagship venture of 1919. Back then Garvey had pointed to Zionism as a model for Pan-Africanists to emulate, and while Padmore saw post-1945 Pan Africanism as distinct from "Black Zionism," he also counseled African nationalists to learn from the way the Jews had built their state. ${ }^{98}$ Zim Navigation, Israel's national shipping company, owned forty percent of the new Black Star Line, and for years Nasser blocked Ghanaian ships from using the Suez Canal.

${ }^{95}$ See George M. Houser, "A Report on the All African People's Conference Held in Accra, Ghana, n.d., Aluka, Electronic Archive http://proxy.library.upenn.edu:9028/action/showMetadata?doi=10.5555/AL.SFF.DOCUMENT.aco a001020\&pgs $=$, accessed January 28, 2009.

${ }^{96}$ Rayford Logan, "The Impending Crisis in Africa," speech given at All Soul's Church, Schenectady, New York, November 21, 1958, Folder 32, Box 27, Speeches, Logan Papers.

${ }^{97}$ Ehud Avriel, "Israel's Beginnings in Africa, 1956-1973: Memoir," in Itamar Rabinovich and Jehuda Reinharz, eds., Israel in the Middle East, Second edition (Lebanon, NH: Brandeis University Press, 2008), pp. 200-204; Zach Levey, “Israel's Entry to Africa, 1956-61," Diplomacy and Statecraft, 12, 3 (2001), pp. 87-114.

${ }^{98}$ Hooker, Black Revolutionary, p. 121. 
Nkrumah's strategy of balancing against Nasser ("little non-alignment") did not survive the sudden death of Padmore in September 1959, the eclipse of Kojo Botsio and others of its supporters, Nasser's greater influence in the circles that Nkrumah would need to win to bring his dream of continental unity to fruition, and Israel's own success in replicating its Ghana strategy with a dozen new African leaders, including Tom Mboya, Julius Neyere, Kenneth Kaunda and most of the Brazzaville group. Even as Nkrumah tried bandwagoning ("big non-alignment") for a while at and following the Cairo and Belgrade meetings of 1961, he continued to rely on the Israeli embassy for intelligence on Egyptian operations across Africa.

Israel's leaders engaged with their new secret weapon against Egypt as we might expect and responded in time honored fashion when their client proved, as clients usually do, hard to coopt. An early message from David Ben Gurion to Nkrumah assured him that "though we belong to the white race we Jews have suffered...at the hands of the white peoples." Yet, when Nkrumah proposed to mediate the conflict with the Arabs, Ben Gurion laughed at his "pretensions." What did the Lion of Israel's agent in Ghana report back as Nkrumah continued to ask for aid even as he questioned aspects of Israeli foreign policy? He has come "unhinged." What we don't know and will likely never know is what Nasser and his clique were saying about their own would be client that nonetheless worked hard for a time to keep the Arab-Israeli dispute off of the Pan-Africa agenda.

\section{VI "The Glorious Era of Nasser and Nkrumah Is Sadly Over""99}

Both students of the cold war and of ideas have their work cut out for them, because, as far as I can tell, what actually went on in a dozens of hurriedly built new national capitals and in the ex-palaces and hotels turned people's conference halls has been distorted in so many dimensions that what we find today are fun-house mirror versions of the past. I have tried to correct a few of the distortions here, using records I began to consult four years ago and that quickly made clear how little we actually know or, better, how much we have forgot. Now, having

${ }^{99}$ Gamal Nkrumah, "Forward Ever," Al-Ahram Weekly. 
read more records from 1955-1959, I would advise returning to the then contemporary political analyses and newspaper accounts and making better use of the now voluminous declassified records. We should probably heed the warning of historians too about the pitfalls of origins stories, particularly since in the one told about Bandung the thing never actually existed.

The 1955 Asian-African Conference did not launch a movement of states, let alone peoples, in support of "decolonization," a term that Padmore denounced for its origins in communist doctrine, preferring instead transfer of power. It is true, however, that if anything even loosely united the twenty-nine mostly self-identified Arab and I won't even begin to try to sort Asian delegations it was the belief that the colonial powers should go out of business sooner rather than later. The 1961 meeting of Non-Aligned States and Heads of Governments was not a follow up to Bandung or its extension. It was its rival.

The tendency to imagine that neutralism-morphed-into-non-alignment kicks off in Asia and then gradually makes its way west to the Mediterranean via Belgrade ought to be rethought. The first scholarly work on neutralism in the early years of the cold war is a case study of mid-1940s France when Le Monde was a recognized exponent of neutralist thought. ${ }^{100}$ Others worked on England "Labor Left."101 Daniel Lerner dissected British and French neutralist trends and communications networks in $1952{ }^{102}$ Tito's links to Asian like-thinking states goes back to the early 1950 s as well. Milovan Djilas led the Yugoslavian delegation to the first Asian Socialist Conference in Rangoon in 1953 as part of Tito's strategy to gain allies in the UN and pursue prospects for a "third bloc," all talk of which was banned by Nehru at Bandung two years later! The Israelis who also identified as neutralist pursued more or less the same strategy as Yugoslavia in Rangoon. ${ }^{103}$ It is not clear why we think the circuits of an idea that matters,

100 John Marcus, Neutralism and Nationalism in France: A Case Study (New York: Bookman Associates, 1958), Lyon, Neutralism, p 19.

101 Leon D. Epstein, "The British Labour Left and U.S. Foreign Policy," American Political Science Review, 45, 4 (December 1951), pp. 974-995.

102 "International Coalitions and Communications Content: The Case of Neutralism," Public Opinion Quarterly 16, 4 (Winter 1952-1953), pp. 681-688.

${ }^{103}$ Rubinstein, Yugoslavia, pp. 40-49, Kyaw Zaw Win, "The Asian Socialist Conference in 1953 as Precursor to the Bandung Conference in 1955," Paper presented at the $15^{\text {th }}$ Biennial 
however easy or hard it is to pin down, should track the obsessions and foreign policy crises of John Foster Dulles, which is what the story does today, not least because of a need to believe in the Bandung Spirit.

Finally the main story arc needs adjusting because Bandung comes toward the end of the first phase of the Cold War although it had little if anything to do with its end. The death of Stalin led to a new round of theorizing and prediction about change in the tight bipolar system (or, if you prefer, the limits of the capacity of either or both of the rival powers to expand the size of their rival empires). Padmore offered up one slightly over zealous version in his running correspondence on tactics and strategy with his protégé.

Now that the Iron Curtain is down and the honeymoon season has started between the Eastern and the Western white folk, the Government must send a mission to see and get ideas from Jugoslavia, where Tito has copied some of the Russian tricks and beaten them at the game. After all, he is the American "darling," so going there is not going "red." 104

That a détente had emerged in the wake of the Berlin and Bay of Pigs crises is undeniable, witness international relations scholars launching the first of their now regular and overblown debates about the prospects for a multipolar system coming into being, while communist theoreticians spoke about polycentrism. ${ }^{105}$ Yugoslavia's own analysis of international affairs took note of the divisions inside various camps that reflected this change. The problem, as Jansen observed, is that it grew increasingly difficult to argue that nonalignment was the only way forward to coexistence and disarmament. Tito seems to have grown increasingly mystical about these matters. ${ }^{106}$ India bailed out of the coalition a year or two after Belgrade. So did China, which tested its first nuclear weapon in October 1964.

Scholars today conflate the movements and thinkers beginning to promote various versions of we-now-confront-the-newest-and-most-insidious-form-of-Western-intervention-yet or

Conference of the Asian Studies Association of Australia, 2004. The Asian delegations came from Burma, Indonesia, India, Israel, Japan, Lebanon, Malaya, Pakistan, and Egypt. There were representatives of African freedom movements from Tunisia, Algeria, Kenya, Nepal, and Uganda.

${ }^{104}$ Padmore to Nkrumah, August 7, 1955, Nkrumah Papers.

${ }^{105}$ William Wohlforth, "Unipolar Stability: The Rules of Power Analysis," Harvard International Review, 29, 1 (Spring 2007), http://hir.harvard.edu/articles/1611/ accessed January 31, 2009.

${ }^{106}$ Jansen, Afro-Asia, p. 367. 
"neocolonialism" in the 1960s both with the Asian-African conference in 1955, where no one was making any arguments remotely like it, and with Belgrade. At Bandung the focus had been liberating the colonial dependencies and protectorates. "By 1962 African expressions of anticolonialism, were generally much stronger than Asian because there were so many more 'vestiges' of (Western) 'colonialism' in Africa." 107 There were those who tried to hold a follow up to the 1955 Asian-African Conference but it never happened, not least because the divisions at the first were real, and no grounds for sustaining that coalition existed on the basis of color, coexistence, or neocolonialism. Instead, Nkrumah and others pushed forward with their idea of a continent-wide Organization of African Unity, while at the UN African states emerged as a selfcontained bloc. The erection of the larger Association of Southeast Asian Nations in 1967 on the foundation of the 1961 three-country (Philippines, Malaysia, and Thailand) Association of Southeast Asia can be seen as a rejection of the radical turn in thought and disastrous economic programs that men like Sukarno (and Nkrumah in Ghana, Nasser in Egypt and others) adopted in the 1960s.

Those concerned with theorizing the role of race in the contemporary international order might return to Romulo's speech at Bandung with profit, because he warned there of the dangers or racialism in their own countries. In the run up to the meeting, British Foreign Office argued that there were no natural grounds for its African dependencies to attend and so should discourage "Asian countries in the idea cherished by many of them that they are the natural saviors and champions of the Africans against the white man." ${ }^{108}$ Nehru was singled out for his meddling where India had no real interests, forgetting the existence of diaspora communities not only in South Africa but also in Uganda, Kenya, and Tanzania. More than a decade earlier, In a remarkable address, "Race, Colonies, and Imperialism," to the National Peace Conference in June 1943 Howard's Rayford Logan also pushed beyond the familiar hierarchy of white overlords and colonial subjects to argue that all forms of "inter-minority oppression" needed to be opposed

\footnotetext{
${ }^{107}$ Lyon, Neutralism, p. 77.

${ }^{108}$ Foreign Office to Middleton, New Delhi, February [undated] 1955, DO 35/6097, original file marking FE 106/287/1 [Far Eastern Dept].
} 
in the future. His examples included the conflicts between Serbs and Croats, Indians and Blacks in South Africa and Kenya, Chinese in Java, and the Mulatto aristocracy in Haiti. ${ }^{109}$

The waves of violence, expropriations, and expulsions witnessed across Asia and Africa in the 1960s and 1970s against Lebanese, Indians, Greeks, Chinese, and so on were licensed by the degenerate turn in so-called progressive thought. ${ }^{110}$ Theories of neocolonialism associated with Sukarno, Nkrumah, and others purported to identify various "anti-nations" within the nation advancing the interests of western imperialism after independence. ${ }^{111}$ It might be the one stark binary of the cold war still in place today.

${ }^{109}$ Folder 42, Box 166-26 Speeches, Logan Papers.

${ }^{110}$ See Robert C. Good, "State-Building as a Determinant of Foreign Policy in the New States, in Lawrence W. Martin, ed., Neutralism and Nonalignment: The New States in World Affairs (New York: Praeger, 1962), pp. 3-12, which predicts the eventual turn on the Indian communities of East Africa as a consequence of the spread of neocolonialism as an ideology.

${ }^{111}$ See the woefully underappreciated Robert Packenham, The Dependency Movement: Scholarship and Politics in Development Studies, Second Printing (Cambridge: Harvard University, 1998 [1992]), p. 45. 